\title{
PENANGANAN FLAT RACK CONTAINER GUNA MENCEGAH TERJADINYA KERUSAKAN MUATAN DI KAPAL MV. MERATUS KALABAHI
}

\author{
A. Kurniawan ${ }^{\text {a }}$, Tri Kismantorob \\ ${ }^{a}$ Taruna Program Studi Nautika PIP Semarang \\ ${ }^{\mathrm{b}}$ Dosen Program Studi Nautika PIP Semarang
}

\begin{abstract}
ABSTRAK
Semakin beragamnya permintaan dari konsumen maka muncul muatan yang tidak beraturan yaitu lebar dan tinggi muatan melebihi batas kemampuan muat container biasa yang membutuhkan penanganan khusus di atas flat rack container. Dari hasil penelitian penulis menemukan adanya kendala koordinasi pihak kapal dengan pihak darat (planner), dalam hal ini adalah perencanaan pemuatan dan pembongkaran. Selain itu petugas jaga tidak melakukan pengecekan pada saat bongkar muat sehingga tidak mengetahui ada muatan yang belum dilashing. Berdasarkan uraian di atas dapat disimpulkan bahwa penanganan muatan flat rack container di kapal MV. Meratus Kalabahi masih belum optimal. Untuk itu sebelum kapal melakukan bongkar muat diadakan komunikasi antara pihak kapal dengan pihak darat dalam hal prosedur penanganan muatan yang benar, serta adanya kerjasama yang baik pada waktu bongkar muat dan melakukan pengecekan secara berkala selama di pelabuhan antara Mualim dan crew kapal yang bertugas, sehingga kualitas muatan tetap terjaga hingga pelabuhan bongkar.
\end{abstract}

\section{Kata kunci : penanganan, muatan, flat rack container}

\section{PENDAHULUAN}

\section{A. Latar Belakang}

Container atau yang dalam bahasa Indonesia sering disebut sebagai peti kemas adalah satu kemasan yang dirancang secara khusus dengan ukuran tertentu, dapat dipakai berulang kali, dipergunakan untuk menyimpan dan sekaligus mengangkut muatan yang ada didalamnya. Filosofi dibalik peti kemas ini adalah adanya kemasan yang terstandar yang dapat dipindah-pindahkan ke berbagai moda transportasi laut dan darat dengan mudah seperti kapal laut, kereta api, truk atau angkutan lainnya sehingga transportasi ini lebih efisien, cepat, dan aman. Dari fungsinya yang mempunyai banyak kemudahan transportasi ini, container akhirnya menjadi pilihan utama pengangkutan barang, terutama untuk lintas pulau atau lintas negara.

Muatan peti kemas dibedakan menurut ukuran (dimensi) dan jenisnya. Ada 3 jenis ukuran container yang lazim digunakan, yaitu 20', 40' dan 45'. Ketiganya tersedia dalam 2 jenis, yaitu standart dan high cube. Perbedaan antara standart dan high cube adalah pada tinggi container. Container high cube mempunyai dimensi tinggi yang lebih daripada container standart, yaitu 9'6" atau sekitar 2,896 m, dibandingkan dengan tinggi container standart, yaitu 8'6" atau sekitar 2,591 m. Container jenis high cube memiliki tanda berupa garis-garis miring dengan warna kuning dan hitam mencolok di atas pintunya. Ketiga container tersebut memiliki perbedaan pada dimensi panjangnya, yaitu $20^{\prime}(6,096 \mathrm{~m}), 40^{\prime}(12,192 \mathrm{~m})$, dan 45' $(13,716 \mathrm{~m})$. Ketiganya memiliki lebar yang sama, yaitu 8 ' atau sekitar 2,438 m. Semua ukuran tersebut adalah ukuran eksteriornya atau bagian luar, sedangkan kerugian sistem container adalah investasinya memerlukan biaya yang cukup besar.

Dengan perkembangan muatan yang semakin komplek dan permintaan dari konsumen yang semakin beragam jenisnya maka muncul muatan dalam bentuk yang tidak beraturan yaitu antara lebar dan tinggi muatan tersebut melebihi batas kemampuan muat container biasa. Muatan ini diharuskan dalam keadaan baik dan tidak rusak sesuai dengan pertama kalinya isi muatan itu dimuat. Butuh penanganan khusus dan benar sesuai dengan prosedur penanganan muatan untuk muatan bebas yang diangkut di atas container yang berbentuk rak datar (flat rack 
container) pada saat pengiriman sampai ke tangan konsumen.

Rencana pemuatan yang mencakup semua peti kemas yang akan dimuat di atas kapal harus sudah direncanakan sebelum kapal tiba di pelabuhan tujuan. Dalam perencanaan yang tidak akurat atau tidak sesuai sering mengakibatkan penundaan keberangkatan kapal. Pengaturan dan pengamanan peti kemas yang baik dan memenuhi aturan pemuatan secara langsung menjamin keselamatan muatan itu sendiri, akan tetapi pada kenyataannya semua hal yang berkaitan dengan pemuatan, pengaturan dan sistem pengamanan peti kemas di atas kapal terkadang tidak sesuai aturan dan kemampuan kapal, sebagai contoh banyak perusahaan pelayaran di Indonesia yang mempunyai manajemen kurang baik khususnya pada kapal peti kemas kurangnya koordinasi antara pihak kapal dengan pihak darat mengenai rencana pemuatan dan pembongkaran yang dilakukan di atas kapal. Rencana pemuatan pada kapal MV. Meratus Kalabahi telah dibuat dan diatur oleh pihak darat, jadi pihak kapal mengetahui rencana pemuatan dan pembongkaran setelah kapal tiba di pelabuhan. Sedangkan pihak kapal ingin merubah bay plan yang telah dibuat oleh pihak darat sesuai prosedur keselamatan kapal, muatan dan keselamatan crew kapal. Hal ini tentu saja membutuhkan beberapa waktu untuk merencanakan pemuatan dan pembongkaran antara pihak kapal dengan pihak darat.

Berdasarkan uraian tersebut di atas penulis tertarik untuk mengadakan penelitian dengan judul "Penanganan Flat Rack Container Guna Mencegah Terjadinya Kerusakan Muatan Di Kapal MV. Meratus Kalabahi“"

\section{B. Rumusan Masalah}

Berdasarkan latar belakang masalah di atas, maka penulis mencoba untuk merumuskan beberapa permasalahan sebagai berikut:

a. Penyimpangan apakah yang terjadi pada penanganan flat rack container di kapal MV. Meratus Kalabahi? b. Bagaimanakah tindakan yang dilakukan untuk menangani flat rack container di kapal MV. Meratus Kalabahi?

\section{Batasan Masalah}

Berdasarkan penelitian yang penulis lakukan dan ditemukan banyaknya permasalahan maka penulis membatasi masalah yang penulis teliti tentang penanganan flat rack container jenis muatan dalam bentuk truk atau beberapa muatan berat yang tidak sesuai dengan ukuran lebar dan tingginya muatan di kapal MV. Meratus Kalabahi.

\section{KAJIAN PUSTAKA}

\section{Pengertian Penanganan}

Menurut Gianto dan Martopo dalam buku Pengoperasian Pelabuhan Laut (2004:23), Penangangan muatan adalah proses penanganan muatan agar selamat sampai ke tempat tujuan. Adapun faktor yang mempengaruhi penanganan muatan, antara lain:

a. Produktifitas bersih, yang didefisinikan sebagai banyaknya penanganan dalam ton untuk tiap crane atau gantry bila bekerja selama 1 (satu) jam tanpa terganggu.

b. Gangguan yang cenderung terjadi pada setiap shift dan dapat menyebabkan waktu menganggur yang mengurangi output shift.

c. Cara buruh bekerja, misalnya berapa banyak waktu lembur dan sebagainya.

Penanganan muatan di pelabuhan yang efisien:

a. Hubungan kerja antara pihak pemilik kapal dan pihak pengusaha pelabuhan yang dalam hal ini bagian terminal di pelabuhan yang bersangkutan.

b. Tersedianya peralatan bongkar muat yang memadai sesuai dengan jenis komoditi yang ditangani.

c. Pengaturan tata letak muatan dalam kapal yang baik.

Menurut Gianto dan Martopo dalam buku Pengoperasian Pelabuhan Laut (2004:02), usaha bongkar muat barang adalah kegiatan jasa yang bergerak 
dalam kegiatan bongkar muat dari dan ke kapal, yang terdiri dari kegiatan stevedoring, cargodoring, dan receiving atau delivery. Dari pengertian di atas penulis mengambil kesimpulan, bahwa proses bongkar muat adalah sebuah kegiatan pemuatan atau pembongkaran yang dilakukan pada saat kapal berada di pelabuhan dengan pengerjaan yang semaksimal mungkin, proses bongkar muat membutuhkan pelayanan jasa bongkar muat, atau yang disebut dengan stevedoring.

\section{Pengertian Muatan}

Menurut Gianto dan Martopo dalam buku Penanganan dan Pengaturan Muatan (2004:7). Demi tercapainya suatu kondisi kualitas yang baik maupun menjaga kualitas muatan sehingga sama dengan keadaan pada waktu muatan itu diterima di kapal maka haruslah kita mengenal betul sebelumnya akan sifat-sifat dari muatan. Muatan-muatan yang diangkut di kapal dapat dibagi dalam golongan-golongan besar menurut sifat-sifatnya (kualitasnya) yaitu diantaranya:

a. Muatan basah adalah muatan yang bersifat basah atau berbentuk cairan yang dikapalkan di dalam kemasan, seperti dalam drum, kaleng, tong dan sebagainya.

b. Muatan cair adalah muatan berbentuk cairan yang dimuat secara curah dalam tangki atau tank container.

c. Muatan kering ialah jenis muatan yang tidak merusak muatan lainnya tetapi dapat rusak oleh muatan lainnya, terutama oleh muatan basah.

d. Muatan kotor adalah muatan yang menimbulkan kotor atau debu selama dan sesudah muat bongkar yang dapat menimbulkan kerusakan pada muatan lainnya terutama muatan bersih dan halus.

e. Muatan bersih adalah muatan yang tidak merusak muatan lainnya karena tidak menimbulkan debu atau kotoran.

f. Muatan berbau adalah jenis muatan yang oleh sifat baunya dapat merusak muatan lain, dan juga dapat saling merusak diantara muatan berbau lainnya.

g. Muatan halus atau peka adalah termasuk diantaranya : tepung terigu, beras, susu bubuk dan bahan kering lainnya. Jenis ini merupakan bahan mudah sekali rusak oleh pengaruh muatan basah, kotor dan berbau.

h. Muatan berbahaya adalah semua jenis muatan yang memerlukan perhatian khusus karena dapat menimbulkan bahaya ledakan.

Muatan berbahaya digolongkan menjadi 9 (sembilan) golongan atau kelas:

1) Explosive

Meliputi barang berbahaya atau bahan peledak yang mempunyai bahaya ledakan, misalnya amunisi dan dinamit.

2) Gasses

Gas yang dimampatkan atau ditekan, dicairkan atau dilarutkan di bawah tekanan.

3) Inflamable Liquids

Cairan yang mudah terbakar. Bahaya utama dari benda ini dalam transportasi adalah dapat mengeluarkan uap (ada jenis dapat beracun).

4) Inflamable Solids

Benda padat yang mudah terbakar. Beberapa jenis dari bahan ini dapat meledak kecuali dicampur dengan air atau cairan lain.

5) Oxidising Agent

Benda atau zat yang mengandung zat asam. Golongan ini dapat menimbulkan uap panas yang dapat terbakar dengan mudah.

6) Poisonus Substance atau Toxic

Benda padat, gas, dan cair yang beracun. Zat ini adalah bahan kimia yang dapat menyebabkan bahaya terhadap kesehatan manusia atau menyebabkan kematiaan apabila terserap ke dalam tubuh karena tertelan, lewat pernafasan atau kontak lewat kulit.

7) Radio Active 
Benda ini adalah benda yang dapat mengeluarkan radiasi yang berbahaya bagi kesehatan manusia dan lingkungannya.

8) Corrosive

Segala macam benda atau bahan yang dapat menimbulkan karat yang bersifat merusak, dapat berbentuk padat maupun cair dalam bentuk aslinya, umumnya bahan ini dapat merusak kulit.

9) Miscellaneous Substance

Ini merupakan jenis benda lain yang berbahaya yang tidak termasuk dari salah satu golongan di atas karena dapat menimbulkan bahaya khusus yang tidak dapat disamakan dengan golongan ini.

Jadi, dari uraian teori di atas penulis mengambil kesimpulan bahwa muatan adalah segala bentuk barang baik padat, cair, maupun gas yang memiliki sifatsifat yang mempunyai karakteristik sendiri yang diangkut dari satu tempat ke tempat lain dengan menggunakan alat transportasi baik darat, laut, maupun udara.

\section{Jenis-Jenis Peti Kemas}

(Sumber:http://www.maritimeworld. web.id/2013/04) Container adalah struktur yang menyimpan berbagai macam produk yang perlu dikirim dari satu tempat ke tempat lain melalui kapal. Dengan demikian, tergantung pada jenis produk yang akan dikirim atau layanan khusus yang diperlukan dari mereka, container dapat bervariasi dalam dimensi, struktur, bahan, dan konstruksinya.

Beberapa jenis yang paling umum dari container pengiriman yang digunakan saat ini antara lain:

\section{a. Dry Storage Container}

Peti kemas jenis ini berfungsi untuk mengangkut berbagai jenis muatan kering atau general cargo yang tidak memerlukan pemeliharaan khusus.

b. Refrigerated ISO Container
Atau disebut juga peti kemas yang mempunyai sistem pengatur udara. Peti kemas ini berfungsi untuk mengangkut muatan beku dengan suhu yang dapat dikontrol, biasanya berisi muatan yang ongkos angkutnya tinggi.

c. Dry Bulk Container

Peti kemas ini cocok untuk mengangkut muatan kering seperti pada kapal curah dan mudah bergeser dengan contoh muatan antara lain: beras, gandum, bijibijian dan lain-lain. Untuk pengisian muatan biasanya mengunakan lubanglubang di bagian atas sebagaimana pintu palka.

d. Open Top Container

Peti kemas ini bagian atasnya terbuka dan mempunyai pintu pada salah satu ujung, peti kemas jenis ini cocok untuk memuat barang-barang yang ukurannya relative besar dan tinggi.

e. Open Side Container

Peti kemas jenis ini mempunyai dinding pada salah satu sisi atau keduaduanya bisa dibuka dan ditutup.

f. Opentop openside container

Peti kemas jenis ini bagian atas serta sisi-sisinya terbuka sedangkan bagian ujung-ujungnya terdapat dinding.

g. Tank Container

Bangunannya berupa sebuah tangki yang dipasang dalam kerangka peti kemas dan sesuai dengan dimensi yang telah ditetapkan oleh ISO (International Standart Organitation). Berfungsi untuk mengangkut muatan yang berbentuk cair dan gas.

h. Flat Rack Container

Peti Kemas jenis ini hanyalah terbentuk dari bagian lantai peti kemas dengan corner casting atau lubang pengangkatnya terletak pada keempat sudutnya, tetapi tanpa mempunyai tiang sudut (corner post). Peti kemas jenis ini tidak bisa dihibob dengan spreader biasa, tetapi saat menghibob menggunakan lift lock sling ataupun spreader biasa yang disambung dengan sling rantai yang dipasang pada keempat sudutnya.

\section{Pencegahan}


Kurniawan $^{\mathrm{a}}$ dan Tri Kismantoro ${ }^{\mathrm{b}}$

Menurut Anwar Hadi (2007:151), pencegahan merupakan tindakan menghilangkan penyebab ketidaksesuaian yang potensial atau situasi yang tidak dikehendaki. Dalam kaitannya dengan upaya pencegahan kerusakan muatan yaitu segala usaha yang dilakukan agar tidak terjadi kerusakan muatan karena penanganan muatan flat rack container yang kurang baik pada saat proses bongkar muat di pelabuhan.

\section{Prinsip Pemuatan}

Menurut Soegiyanto (2004:08) dalam pemuatan dan pembongkaran muatan harus dilaksanakan secara cepat, efisien dan sistematis. Agar pelaksanaan pemuatan dan pembongkaran dapat dilakukan secara cepat dan sistematis, maka sebelum kapal tiba di pelabuhan pertama (first port), harus sudah tersedia rencana pemuatan dan pembongkaran (stowage plan). Stowage plan ini merupakan rencana awal (tentative stowage plan), jadi apabila terjadi perubahan rencana masih dapat dilakukan. Setelah rencana awal dilaksanakan secara keseluruhan di pelabuhan tersebut, baru disalin ke dalam pemuatan akhir (final stowage plan). Kalau sudah final stowage plan, maka muatan tidak boleh dirubah, kecuali dalam keadaan yang sangat memaksa.

Menurut Alam S. (2007:140), pelaksanaan adalah suatu fungsi manajemen untuk menggerakkan orangorang agar bekerja sesuai dengan tujuan yang telah ditetapkan. Banyak orang mengambil kesimpulan bahwa fungsi manajemen pelaksanaan merupakan fungsi yang paling penting karena berhubungan dengan sumber daya manusia.

Berdasarkan definisi tersebut, penulis menyimpulkan bahwa dalam pelaksanaan harus terdapat koordinasi agar mencapai keefektifitasan dalam suatu kegiatan.

Menurut Martopo dan Soegiyanto (2004:7), stowage atau penataan muatan merupakan suatu istilah dalam kecakapan pelaut, yaitu suatu pengetahuan tentang memuat dan membongkar muatan dari dan ke atas kapal sedemikian rupa agar terwujud 5 prinsip pemuatan yang baik.

Adapun 5 (lima) prinsip pemuatan yang baik adalah:

a. Melindungi awak kapal dan buruh (safety of crew and longshoreman).

Hal-hal yang perlu diperhatikan adalah penggunaan alat-alat keselamatan kerja secara benar, pemeriksa peralatan bongkar muat sebelum digunakan sehingga dalam keadaan baik serta mengadakan tindakan berjaga-jaga secara benar.

b. Melindungi kapal (to protect the ship) Melindungi kapal adalah suatu upaya agar kapal tetap selamat selama kegiatan muat bongkar maupun dalam pelayaran, misalnya menjaga stabilitas kapal, jangan memuat melebihi deck load capacity, memperhatikan SWL (safety working load) peralatan muat bongkar.

c. Melindungi muatan (to protect the cargo)

Dalam peraturan perundang-undangan internasional dinyatakan bahwa perusahaan atau pihak kapal bertanggungjawab atas keselamatan dan keutuhan muatan sejak muatan itu dimuat sampai muatan itu dibongkar. Oleh karena itu pada waktu memuat, membongkar, dan selama dalam pelayaran, muatan harus ditangani secara baik.

d. Melakukan muat bongkar secara cepat dan sistematis (rapit and systematic loading and discharging).

Agar pelaksanaan pemuatan dan pembongkaran dapat dilakukan secara cepat dan sistematis, maka sebelum kapal tiba di pelabuhan pertama, harus sudah tersedia rencana pemuatan dan pembongkaran (stowage plan).

e. Penggunaan ruang muat semaksimal mungkin.

Dalam melakukan pemuatan harus diusahakan agar semua ruang muat dapat terisi penuh oleh muatan atau kapal dapat memuat sampai sarat 
maksimum, sehingga dapat diperoleh uang tambang yang maksimal.

\section{Jenis-jenis Kapal Peti Kemas}

(Sumber:http://www.academia.edu/52074 32/KAPAL LAUT DAN MUATAN) Jenis-jenis kapal peti kemas diantaranya sebagai berikut:

a. Kapal Semi Container

Kapal semi container adalah kapal yang biasa digunakan untuk mengangkut peti kemas bersama-sama dengan muatan yang tidak dimuat dalam peti kemas (break bulk), dengan kata lain muatan yang dibungkus secara konvensional.

\section{b. Kapal Full Container}

Kapal jenis ini digunakan hanya untuk mengangkut peti kemas. Pada ruanganruangan muat sudah dipasang cell guide sehingga peti kemas yang akan dimuat kedalam ruang muat dapat dengan mudah diarahkan melalui cell guide. Di atas geladak kapal biasanya juga dipasang cell guide. Selain berfungsi untuk mengarahkan peti kemas pada tempat kedudukannya di dalam palka (in hold) dan di atas palka (on deck), cell guide juga berfungsi sebagai penahan peti kemas terhadap gaya-gaya kapal yang timbul pada saat kapal berlayar di laut bebas.

\section{Bay Plan Container}

Container Bay Plan adalah rencana muatan yang dibuat atau direncanakan sebelum pemuatan container, atau menurut (Tim PIP Semarang, 2001:163) container bay plan adalah bagan pemuatan peti kemas secara membujur, melintang dan tegak. Membujur ditandai dengan nomor bay mulai dari depan ke belakang, dengan catatan nomor ganjil untuk peti kemas ukuran 20 feet atau TEUS (twenty feet equivalent unit) dan nomor genap untuk peti kemas ukuran 40 feet atau FEUS (fourty feet equivalent unit). Tier dihitung dari bawah ke atas. Melintang ditandai dengan nomor row dimulai dari tengah dan dilihat dari belakang. Bay Plan biasanya berbentuk buku dengan lembaran-lembaran untuk masing-masing bay. Dengan banyaknya jenis peti kemas yang dimuat, di dalam container bay plan diberi tanda-tanda jumlah berat muatan dan posisinya sesuai bay, row, atau tier untuk memperlancar proses bongkar muat.

\section{METODOLOGI PENELITIAN}

Metode penelitian adalah suatu kegiatan ilmiah yang terencana, terstruktur, sistematis dan memiliki tujuan tertentu baik praktis maupun teoritis. Dikatakan sebagai 'kegiatan ilmiah' karena penelitian dengan aspek ilmu pengetahuan dan teori. 'Terencana' karena penelitian harus direncanakan dengan memperhatikan waktu, dana dan aksesibilitas.

Metode Deskriptif merupakan suatu metode dalam meneliti status sekelompok manusia, suatu objek, suatu sistem pemikiran ataupun suatu kelas peristiwa pada masa sekarang. Tujuan dari penelitian deskriptif ini adalah untuk membuat deskriptif, gambaran atau lukisan secara sistematis, faktual dan akurat mengenai fakta-fakta, sifat-sifat serta hubungan antar fenomena yang diselidiki.

\section{ANALISIS DATA DAN HASIL PENELITIAN}

\section{Analisis Data}

Berdasarkan analisa yang dilakukan, penulis dalam penyusunan penelitian ini akan membahas beberapa permasalahan yang terjadi sehubungan dengan penanganan muatan yang dilakukan di kapal MV. Meratus Kalabahi ini. Dimana permasalahan tersebut yaitu:

a. Adanya penyimpangan yang terjadi terhadap penanganan flat rack container di kapal MV. Meratus Kalabahi.

Dari hasil observasi terhadap obyek secara langsung di lapangan, penyusun menemukan bahwa pelaksanaan penanganan flat rack container di MV. Meratus Kalabahi tidak sesuai dengan prosedur. Banyak hal yang menjadi penghambat dari pelaksanaan kegiatan tersebut, diantaranya yang pernah dialami penulis adalah:

1) Proses penanganan yang kurang baik dan disebabkan oleh lemahnya koordinasi antara pihak kapal dengan pihak darat (planner). 
Sehingga proses bongkar muat mengalami perlambatan jam kerja dan mengakibatkan kerugian bagi perusahaan karena harus membayar uang tambahan waktu sandar. Contoh kasus : Pada saat kapal MV. Meratus Kalabahi tiba di pelabuhan Surabaya dan akan melakukan bongkar muat. Pihak darat (planner) datang ke kapal dengan membawa laporan rencana pemuatan dan pembongkaran. Sesuai dengan bay plan container yang sudah dibuat oleh pihak darat (planner) terjadi kesalahan penempatan muatan jenis flat rack container yang tidak sesuai dengan prosedur keselamatan di atas kapal. Muatan tersebut diketahui setelah kapal akan selesai melakuakan kegiatan memuat di pelabuhan Surabaya. Pihak darat (planner) salah memberi tanda bahwa muatan flat rack container tersebut tertulis $d r y$ container sehingga dalam bay plan ditempatkan pada tier pertama. Hal ini tentu saja sangat menyimpang, muatan flat rack container tidak bisa ditempatkan pada tier pertama karena akan sangat mengganggu apabila tier kedua masih ditempati muatan. Sehingga Mualim I memanggil planner dan menyuruh operator crane untuk memindahkan muatan tersebut. Kesalahan penempatan flat rack container pada bay plan yang telah dibuat oleh pihak darat sangat mengganggu operasional kapal. Muatan yang telah dimuat di atas kapal memaksa untuk dilakukan pembongkaran kembali dan menyusun muatan secara benar sesuai dengan prosedur di kapal. Hal ini menghambat keberangkatan kapal.

2) Tidak dilakukan pengecekan pada saat bongkar muat. Contoh kasus: Pada saat akan melaksanakan tugas jaga di pelabuhan seringkali juru mudi ataupun kadet menyepelekan memberi informasi melalui telepon kapal setengah jam sebelum melaksanakan tugas jaga. Padahal waktu setengah jam sebelum jaga wajib di informasikan kepada Mualim, juru mudi dan kadet dek. Informasi sangat membantu untuk petugas jaga selanjutnya agar mempersiapkan diri baik fisik maupun mental. Akibatnya petugas jaga pengganti belum siap untuk melaksanakan tugas jaganya. Kasus yang pernah penulis alami adalah pada saat memuat flat rack container, dimana muatan flat rack container tersebut belum di-lashing padahal kapal akan segera berangkat. Hal ini tentu saja sangat membahayakan bagi keselamatan kapal, muatan dan tanggung jawab serta kerugian yang akan dialami karena kelalaian dalam menjalankan tugas pada saat kapal memuat.

Dari penelitian data yang penulis uraikan sebelumnya, maka permasalahan yang dialami pada saat pelaksanaan penanganan flat rack container adalah kurangnya koordinasi antara pihak kapal dan darat (planner) dalan membuat bay plan container dan tidak dilakukan pengecekan pada saat bongkar muat. Chief officer sangat berperan penting dalam pelaksanaan kegiatan tersebut baik secara manajemen maupun koordinasi dengan berbagai pihak yang terkait. Tidak hanya itu, tanggung jawab petugas jaga juga berpengaruh terhadap kelancaran bongkar muat.

b. Tindakan yang dilakukan untuk menangani flat rack container

Dari hasil observasi terhadap objek secara langsung di lapangan, penyusun menemukan beberapa dari tindakan yang dilakukan untuk menangani flat rack container yaitu antara lain:

1) Pengecekan dokumen muatan

Persiapan yang menyangkut dokumen muatan merupakan 
persiapan awal sebelum mempersiapkan sarana yang lain. Hal ini dilakukan mengingat bahwa dengan dokumen muatan kita sudah mendapatkan informasi yang cukup jelas tentang jenis, jumlah, ukuran serta sifat barang-barang yang akan dibongkar dari kapal. Dokumendokumen khusus yang berkaitan dengan pembongkaran barangbarang impor antara lain:

\section{1). Cargo manifest}

Cargo manifest atau cargo declaration adalah dokumen yang memperlihatkan daftar semua barang beserta perincian nama barang, berat dan jenis barang yang diangkut oleh suatu kapal untuk dimuat dan dibongkar di beberapa pelabuhan.

2). Daftar muatan khusus (special cargo list)

Daftar muatan ini memuat perincian tentang jumlah dan jenis muatan-muatan yang dikategorikan muatan khusus, misalnya: barang-barang berbahaya, muatan bernilai tinggi, muatan berat, muatan memerlukan udara dingin, muatan dengan berat dan volume yang melebihi kemampuan muat container biasa dimana muatanmuatan ini membutuhkan penanganan secara khusus.

3). Daftar muatan palka (hatch list) Setiap palka mempunyai muatan sendiri-sendiri sehingga setiap palka diperinci tersendiri pula terhadap muatan-muatan yang ada di dalamnya dan ketika muatan akan dibongkar, kita dapat barang-barang di palka mana yang akan dibongkar di atas kapal.

4). Daftar muatan khusus (special cargo list), sering barang berbahaya ditetapkan oleh International Marine Organization (IMO) dibuatkan daftar tersendiri, sehingga memudahkan untuk pembongkaran dan pemuatannya di pelabuhan tujuan.

5). Daftar bongkar muat kapal (ships cargo discharging list).

Daftar ini memperinci barang yang akan dibongkar dari kapal pada setiap pelabuhan yang akan disinggahi. Dari daftar ini kita dapat melihat adakah muatan yang akan dibongkar di pelabuhan dimana kapal itu tiba. Kadang-kadang kapal tiba di suatu pelabuhan tidak membongkar muatan, melainkan hanya akan memuat muatan.

2) Pengecekan letak posisi muatan sesuai bay plan container.

Pengecekan letak posisi muatan sesuai bay plan container di atas kapal itu sangat penting. Agar muatan tersebut tidak salah diletakkan pada posisinya. Karena jika salah meletakkan, maka akan berbahaya bagi keselamatan jiwa dan kapal. Maka dari itu dibuatlah rencana pengaturan muatan yang mempunyai tujuan untuk mengetahui dimana diletakkan dengan berat muatan tersebut, palka siap untuk menahan beban muatan tersebut, dan mengatur untuk pembongkaran di tujuan pelabuhan tertentu.

3) Kerjasama yang baik antar petugas jaga dalam pelaksanaan tugas jaga.

Tugas jaga pelabuhan adalah suatu pekerjaan jaga yang dilakukan di pelabuhan untuk menciptakan situasi dan kondisi aman dan terkendali. Dalam hal ini mengandung pengertian bahwa dalam pelaksanaan dinas jaga diperlukan suatu usaha untuk mengawasi atau mempertahankan jalannya suatu kegiatan yang berhubungan dengan kegiatan bongkar muat, supaya pelaksanaannya bisa berjalan dengan cepat, lancar dan aman. Supaya dalam pelaksanaan 
dinas jaga pelabuhan bisa berjalan sesuai dengan yang diinginkan, maka Mualim I membuat daftar jaga untuk menjadi suatu kewajiban dan tanggungjawab petugas jaga terhadap tugas yang diberikan selama jam jaganya. Jadi para perwira jaga maupun juru mudi sudah mempunyai tanggung jawabnya masing-masing. Dalam melaksanakan dinas jaga di pelabuhan berbeda dengan melaksanakan dinas jaga di laut. Berdasarkan penelitian pengaturan tugas jaga di pelabuhan di lakukan hanya dua orang perwira jaga yaitu Mualim II dan Mualim III dan dibantu oleh juru mudi dan kadet. Mualim I hanya mengatur jam jaga pelabuhan selama 12 jam selama 2 periode. Jam jaga untuk Mualim II dari jam 12.00-18.00 dan 00.0006.00 sedangkan Mualim III dari jam 06.00-12.00 dan 18.00-24.00. Pengaturan tugas jaga ini harus dilakukan karena untuk melancarkan operasional kapal.

4) Pengawasan terhadap lashingan muatan.

Pengawasan sangatlah penting dilakuakan oleh petugas jaga, baik itu Mualim II atau Mualim 3, juru mudi serta kadet deck. Dengan pengawasan yang baik maka kegiatan bongkar muat dapat berjalan baik cepat, efektif, dan terjaga keamaan serta keselamatan kerjanya.

\section{Pembahasan Masalah}

Berdasarkan hasil observasi, wawancara dan juga tinjauan pustaka untuk berbagai permasalahan yang ditemukan di atas kapal dengan kasus yang dialami peneliti selama praktek laut, maka upaya untuk memaksimalkan kerjasama antar semua awak kapal dalam penanganan muatan flat rack container adalah sebagai berikut:

a. Adanya penyimpangan yang terjadi terhadap penanganan flat rack container di kapal MV. Meratus Kalabahi.

Berikut ini peneliti jelaskan tentang apa saja penyimpangan yang terjadi saat dilakukannya kegiatan bongkat muat muatan flat rack container di kapal MV. Meratus Kalabahi:

1) Kurangnya koordinasi antara pihak kapal dan darat (planner) dalam membuat bay plan container.

Kesalahan akan penempatan muatan adalah salah satu pokok utama yang menjadi inti permasalahan. Saat dilakukan kegiatan bongkar muat di pelabuhan semua petugas jaga wajib mengecek ulang akan bay plan yang sudah dibuat dan disetujui oleh Mualim I sehingga bila terjadi kesalahan penempatan muatan dapat segera diatasi, bukan saat muatan sudah akan selesai dimuat baru diketahui namun saat kegiatan baru dimulai untuk muatan on deck. Maka dari itu perlunya meningkatkan koordinasi antara kedua belah pihak agar tercapainya suatu kegiatan yang teratur serta menghasilkan tindakan yang tepat pada sasaran. Pihak darat sebaiknya memberikan informasi ketika kapal dalam perjalanan menuju ke pelabuhan muat bukan pada saat kapal sandar baru informasi bay plan serta muatan diberikan. Sehingga Mualim I dalam hal ini sebagai penanggung jawab muatan dapat mengkoreksi isi berita pemuatan dan segera diberitakan bila terdapat kesalahan penempatan muatan flat rack container yang tidak sesuai dengan prosedur keselamatan muatan yang nantinya berdampak pada kerusakan muatan.

2) Tidak dilakukan pengecekan pada saat bongkar muat.

Pemeriksaan ataupun disebut juga pemeriksaan erat kaitannya dengan tanggung jawab ketika 
melaksanakan tugas jaga di pelabuhan. Khususnya pada saat kapal melakukan kegiatan bongkar muat. Lalainya kewajiban akan pengecekan terhadap muatan ketika kegiatan memuat sedang berlangsung sangat berdampak negatif pada keamanan akan muatan tersebut. Kelalaian ini disebabkan karena kurangnya kedisiplinan petugas jaga dalam menjalankan tugasnya. Petugas jaga tidak melakukan serah terima jaga dengan baik. Petugas jaga biasanya setengah jam sebelum jam jaganya selesai telah meninggalkan pos jaganya sedangkan petugas jaga penggantinya belum datang melainkan masih melaksanakan pesiar. Hal ini tentunya sangatlah disayangkan karena kesadaran akan tanggung jawab kerja sangatlah lemah. Untuk itu demi menjaga keamanan dan keselamatan pada saat berlayar maka sebaiknya diadakan pengecekan terhadap kondisi muatan dengan cermat dan teliti dengan memperhatikan kondisi lashingan muatan yang ada di atas palka. Bila salah segera diperbaiki dan bila belum diberi lashing maka ditangani agar kualitas muatan tetap terjada dalam kondisi baik dan tidak mengalami kerusakan.

b. Penanganan muatan flat rack container di kapal MV. Meratus Kalabahi.

1) Pengecekan dokumen muatan serta letak posisi muatan sesuai bay plan

Sebelum kapal tiba di pelabuhan tujuan Mualim I wajib mengecek ulang berita rencana muatan yang akan dimuat di atas kapal. Pada saat melakukan pemuatan peti kemas berbahaya, pihak darat (planner) datang ke kapal dan menyerahkan bay plan kepada Mualim I. Pihak darat harus memberitahukan tentang jumlah muatan berat yang akan dimuat di dalam flat rack container, jika ada maka wajib memberikan cargo manifets. Isi dari cargo manifest adalah menginformasikan tentang:

a) Pelabuhan muat dan pelabuhan bongkar.

b) Posisi pemuatan di atas deck (bay, row, tier).

c) Isi muatan atau jenis muatan.

d) Jumlah berat muatan.

e) Class of cargoes

Pada saat kapal tiba di pelabuhan muat dan bongkar, maka Mualim I melakukan komunikasi secara langsung (lisan) dengan pihak darat (planner) dan apabila ada kesalahan pihak darat dalam pembuatan bay plan container, maka Mualim I wajib memberikan informasi yang benar dan sesuai prosedur dengan mempertimbangkan keselamatan manusia, kapal dan muatannya.

Agar pelaksanaan bongkar muat di pelabuhan dapat dilakukan secara sistematis dan efisien, maka sebelum proses bongkar muat di pelabuhan Mualim I harus mengetahui penempatan muatan flat rack container menurut jenisnya isi muatan masing-masing. Mualim I wajib menginformasikan seluruh muatan yang akan dimuat dan yang akan dibongkar sesuai dengan bay plan container kepada Mualim jaga. Sebagai Mualim jaga mempunyai tanggung jawab atas muatan selama proses bongkar muat. Mualim jaga wajib mengetahui dan memahami bay plan yang telah dibuat dengan memperhatikan muatan-muatan yang akan dibongkar dan dimuat.

2) Kerjasama yang baik antar petugas jaga dalam pelaksanaan tugas jaga

Di atas kapal MV. Meratus Kalabahi pelaksanaan tugas jaga pada saat kapal di pelabuhan dilakukan secara periode atau bergantian. Periode pergantian jam jaga pelabuhan dilakukan setiap enam jam selama dua kali sehari. Biasanya yang melakukan jaga pada saat kapal sandar di pelabuhan yaitu 
Mualim II dan Mualim III ditemani oleh satu juru mudi dan kadet dek pada saat jaga. Pelaksanaan tugas jaga di pelabuhan merupakan suatu hal yang menjadi tanggung jawab oleh Mualim jaga, juru mudi jaga, dan juga kadet. Diantaranya tugastugas yang harus di perhatikan selama jaga di pelabuhan adalah:

a) Keadaan muatan

Sebelum muatan dimuat di atas kapal maupun dibongkar dari kapal hendaknya melakukan pengecekan terhadap kondisi muatan tersebut. Hal ini sangat berpengaruh terhadap keadaan peti kemas beserta isinya. Jika terjadi kerusakan muatan maka tugas dari Mualim jaga untuk segera melaporkan kepada Mualim I untuk diinformasikan kepada pihak darat (planner) bahwa muatan tersebut rusak dan tidak bisa diangkut di atas kapal. Jika terpaksa mengangkut maka Mualim I harus mengetahui seberapa parah kerusakan peti kemas yang akan diangkut dan harus ada persetujuan bukti antara Mualim I dengan planner yang menyatakan muatan tersebut telah rusak dan dengan terpaksa diangkut dikarenakan muatan harus segera sampai ke tempat tujuan.

b) Stabilitas kapal selama sandar

Selama kapal sandar di pelabuhan stabilitas kapal juga perlu diperhatikan karena dapat mengganggu proses bongkar muat selama di pelabuhan. Jika keadaan kapal dalam posisi yang tidak rata atau miring kanan maupun kiri. Muatan akan susah ditempatkan dan bisa saja terjadi muatan yang jatuh ke laut. Jadi tugas Mualim jaga harus memperhatikan letak muatan dan juga tangki-tangki balast.

c) Keamanan di atas kapal.
Di atas kapal telah diterapkan berbagai cara untuk menghindari pencurian dan penyelundupan barang maupun manusia. Maka dari itu diwajibkan kepada seluruh kapal agar memberikan petugas keamanan (Ship Security Officer) berarti seorang di atas kapal yang bertanggung jawab kepada nahkoda yang ditunjuk oleh perusahaan yang bertanggung jawab untuk keamanan kapal mencakup implementasi dan untuk koordinasi dengan petugas keamanan perusahaan dan petugas keamanan fasilitas pelabuhan.

d) Tali-tali tambat

Tali tambat digunakan untuk mencegah terjadinya keadaan kapal menjauh dari dermaga. Keadaan tali tambat perlu dijaga kekencangannya pada saat mengikat di bolder kapal. Sebab jika kekencangan tidak diperhatikan maka tali tross tersebut bisa putus dan mengakibatkan kapal akan renggang dengan tepi dermaga. Namun jika tali tambat terikat pada winch, otomatis apabila tali tersebut kencang maka akan mengendor dengan sendirinya.

e) Pengawasan terhadap lashingan muatan.

Pengawasan sangatlah penting dilakukan oleh petugas jaga, baik itu Mualim 2 atau Mualim 3, juru mudi serta kadet dek. Dengan pengawasan yang baik maka kegiatan bongkar muat dapat berjalan baik cepat, efektif, dan terjaga keamaan serta keselamatan kerjanya. Mengenai pengawasan terhadap lashingan muatan tentunya petugas jaga terjun langsung mengamati setiap container yang dimuat di atas palka (on deck) dengan memper- 
hatikan pada setiap corner casting atau lubang sepatu telah diisi di keempat sudutnya. Setelah itu petugas jaga memeriksa dan memastikan bahwa keempat lubang corner casting tersebut telah masuk semua ke dalam base cone container. Selanjutnya petugas jaga mengawasi kegiatan buruh dalam melashing muatan menggunakan lashing bar dan turnbuckle. Kemudian memeriksa diatara container telah dipasang bridge fitting agar tidak terjadi pergeseran antar container saat terjadi cuaca buruk di laut serta yang terkhir memastikan semuanya telah terpasang dengan kencang, aman, dan sesuai dengan prosedur.

\section{PENUTUP}

\section{Kesimpulan}

Penulis dalam bab ini akan mengemukakan beberapa kesimpulan mengenai penanganan muatan flat rack container yang terjadi di atas kapal container MV. Meratus Kalabahi. Terdapat beberapa penyimpangan yang mempengaruhi terlaksananya penanganan muatan tersebut. Dari pembahasan di atas, penulis dapat menarik kesimpulan sebagai berikut:

a. Penyimpangan yang terjadi pada penanganan flat rack container di kapal MV. Meratus Kalabahi yaitu diantaranya adalah:

1) Kurangnya koordinasi antara pihak kapal dan darat (planner) dalam membuat bay plan container

2) Tidak dilakukan pengecekan pada saat bongkar muat

b. Penanganan muatan flat rack container di kapal MV. Meratus Kalabahi :

1) Pengecekan dokumen muatan serta letak posisi muatan sesuai bay plan

2) Kerjasama yang baik antar petugas jaga dalam pelaksanaan tugas jaga
3) Pengawasan terhadap lashingan
muatan

\section{Saran}

Sebagai langkah perbaikan dimasa mendatang maka penulis menyarankan beberapa hal yang diharapkan dapat melengkapi teori yang sudah ada dan dapat diambil manfaatnya bagi semua pembaca. Adapun saran dari penulis antara lain:

a. Pihak kapal sebaiknya lebih memperhatikan bay plan container yang diberikan oleh pihak darat, sehingga dalam pelaksanaan penanganan muatan flat rack container di atas kapal dapat berlangsung secara optimal serta petugas jaga sebaiknya melakuakan serah terima jaga dengan baik dan pengecekan kondisi muatan saat kegiatan bongkar muat sedang berlangsung.

b. Crew kapal sebaiknya lebih cermat lagi dalam memeriksa rencana pemuatan yang diberikan oleh planner serta sebaiknya lebih ditingkatkan lagi pengawasan terhadap keadaan muatan dan keamanan kapal.

\section{DAFTAR PUSTAKA}

Gianto dan Martopo. 2004. Pengoperasian Pelabuhan Laut. Semarang: Politeknik Ilmu Pelayaran

Hadi, Anwar. 2005. Pemahaman dan Penerapan ISO/EIC 17025:2005. Jakarta: PT Ikrar Mandiriabadi

Martopo, Arso dan Soegiyanto. 2004. Penanganan dan Pengaturan Muatan. Semarang: Politeknik Ilmu Pelayaran

Moleong, Lexy J. 2006. Metodologi Penelitian Kualitatif. Bandung: PT. Remaja Rosdakarya

Nasution. 2003. Metode Research. Jakarta:

PT. Bumi Aksara 
Penanganan Flat Rack Container Guna Mencegah Terjadinya Kerusakan Muatan di Kapal MV. Meratus Kalabahi

Kurniawan $^{\text {a }}$ dan Tri Kismantoro ${ }^{\mathrm{b}}$

PIP. 2001. Memuat untuk Perwira Kapal Niaga. Semarang: Politeknik Ilmu Pelayaran

Suryabrata, Sumadi. 2003. Metodologi Penelitian. Yogyakarta: PT. Raja Grafindo Universitas Gajah Mada

Taylor, Bogdan. 2007. Qualitatif Research For Education. Boston: Alynan Dacon

Tim Penyusun. 2002. Badan Diklat Pemutakhiran ANT-II. Semarang: Politeknik Ilmu Pelayaran 